\title{
Earthworm Diversity, Forest Conversion and Agroforestry in Quang Nam Province, Vietnam
}

\author{
Rachmat Mulia ${ }^{1}$, Sam Van Hoang ${ }^{2, *}$, Van Mai Dinh ${ }^{3}$, Ngoc Bich Thi Duong ${ }^{4}$, Anh Duc Nguyen ${ }^{5,6}$, \\ Dang Hai Lam ${ }^{7}$, Duyen Thu Thi Hoang ${ }^{8}$ and Meine van Noordwijk ${ }^{9}{ }^{\mathbb{D}}$
}

check for

updates

Citation: Mulia, R.; Hoang, S.V.; Dinh, V.M.; Duong, N.B.T.; Nguyen, A.D.; Lam, D.H.; Thi Hoang, D.T.; van Noordwijk, M. Earthworm Diversity, Forest Conversion and Agroforestry in Quang Nam Province, Vietnam. Land 2021, 10, 36. https://doi.org/ 10.3390/land10010036

Received: 30 October 2020 Accepted: 30 December 2020 Published: 4 January 2021

Publisher's Note: MDPI stays neutral with regard to jurisdictional clai$\mathrm{ms}$ in published maps and institutional affiliations.

Copyright: (C) 2021 by the authors. Licensee MDPI, Basel, Switzerland. This article is an open access article distributed under the terms and conditions of the Creative Commons Attribution (CC BY) license (https:// creativecommons.org/licenses/by/ $4.0 /)$.
1 World Agroforestry (ICRAF), Hanoi 100000, Vietnam; r.mulia@cgiar.org

Department of Forest Plant, Vietnam National University of Forestry, Hanoi 100000, Vietnam

Department of Soil, Vietnam National University of Forestry, Hanoi 100000, Vietnam; vandm@vnuf.edu.vn

4 Department of Environmental Engineering, Vietnam National University of Forestry, Hanoi 100000, Vietnam; ngocdtb@vnuf.edu.vn

5 Department of Soil Ecology, Institute of Ecology and Biological Resources, Vietnam Academy of Science and Technology, Hanoi 100000, Vietnam; ducanh@iebr.ac.vn

6 Department of Ecology and Biological Resources, Graduate University of Technology and Science, Vietnam Academy of Science and Technology, Hanoi 100000, Vietnam

7 Department of Biology, School of Education, Can Tho University, Can Tho 900000, Vietnam; Lhdang@ctu.edu.vn

8 Climate Change and Development Program, Vietnam-Japan University, Vietnam National University, Hanoi 100000, Vietnam; htt.duyen@vju.ac.vn

9 World Agroforestry (ICRAF), Bogor 16155, Indonesia; m.vannoordwijk@cgiar.org

* Correspondence: samhv@vnuf.edu.vn; Tel.: +84-983-33-78-98
Abstract: The conversion of natural forests to different land uses still occurs in various parts of Southeast Asia with poor records of impact on ecosystem services and biodiversity. We quantified such impacts on earthworm diversity in two communes of Quang Nam province, Vietnam. Both communes are situated within buffer zones of a nature reserve where remaining natural forests are under threat of continued conversion. We identified 25 different earthworm species, out of which 21 were found in natural forests, 15 in agroforestry, 14 in planted forests, and seven each in annual croplands and home gardens. Out of the six species that were omnipresent inhabitants of all observed habitats, Pontoscolex corethrurus largely dominated habitats with intensive anthropogenic activities but was rare in natural forests. Natural and regenerated forests had a much denser earthworm population in the top $10 \mathrm{~cm}$ of soil rather than in deeper soil layers. We conclude that the conversion of natural forests into different land uses has reduced earthworm diversity which can substantially affect soil health and ecosystem functions in the two communes. Protection of the remaining natural forests is urgent, while the promotion of a tree-based farming system such as agroforestry can reconcile earthworm conservation and local livelihoods.

Keywords: land-use change; belowground biodiversity; soil engineers; Pontoscolex corethrurus; natural habitats; planted forest

\section{Introduction}

The inclusion of 'planted forest' in forest statistics has been a major factor in the 'forest transition' concept: the reversal after long periods of decline towards a net gain in forest area $[1,2]$. Forest statistics can thus mask the ongoing loss of natural forest by larger gains in planted forest area, even though in terms of ecosystem services old-growth natural forests are very different from young planted forests [3]. Beyond the direct benefits that land-use change brings (or is expected to bring) to land users, a wide range of 'externalities' are generated, changes that do not play a role in the land users' decision making [4]. Where such externalities are negative for others in the landscape, corrective action is needed 
in the form of regulations or incentives; where they are positive, forms of incentives are appropriate [5].

Many of the ecosystem services that, as externalities of decision-making, are influenced by land use are controlled by soil conditions [6]. Beyond vegetation with its aboveground litter and plant root systems and turnover, microbes, fungi, and soil fauna are important for modifying the soil conditions that in turn shape soil structure (pores, aggregates) influencing water flows and storage and net greenhouse gas emissions that determine ecosystem services [7]. As part of the global loss of biodiversity, loss of belowground biodiversity and its impact on ecosystem services is still poorly understood [8,9]. Changes in the soil can be relatively slow to be noticed by soil biota, as the system is buffered in many aspects, but once undesirable changes take place, they are also hard to correct, especially if they reach soil layers below the surface [10], as thresholds are past where both roots and earthworms have difficulties penetrating [11]. Better knowledge of changes in belowground biodiversity in the context of 'forest transition' patterns of land-use change is urgent for many parts of the tropics, especially.

Over the past decades, Vietnam's forest cover has continued to expand from $28 \%$ in 1993 to $42 \%$ in 2018 [12]. Policy reforms and nation-wide forest protection and replanting programs have been the main drivers $[13,14]$. Forest expansion, including planted forests, has substantially contributed to economic growth, job creation, and poverty alleviation in the country [12]. However, despite the increasing trend, the conversion and degradation of natural forests still occur in different parts of the country. The existing natural forests in Vietnam are largely in poor condition or regenerating [12]. The forest cover rates overlook forest quality. Competing land uses, exploitation of forest resources, and weak forest governance are serious challenges for the country to protect the remaining and regenerating poor natural forests [12]. Massive conversion of natural forests still occurs for example in the Central Highlands and Central Annamites region of the country. The expansion of commercial crops and infrastructure development have been the main drivers of forest conversion in Central Highlands [15]. In the Central Annamites, considered as one of the largest continuous natural forest areas and key biodiversity landscapes in Asia, forest resources and wildlife are continuously under threat of intensive exploitation by surrounding forest-dependent populations [16,17].

Concerns over the impacts of forest conversions on ecosystem services and biodiversity have recently become more prominent in Vietnam [18,19]. Several sub-national and national policies to include the 2011-2020 National Biodiversity Strategy with vision to 2030 underline the need of taking up existing scientific- and evidence-based information and undertaking further research on such impacts while strengthening forest protection efforts. Several studies from other parts of the world have reported impacts of forest conversions on biodiversity including belowground biodiversity (e.g., [20,21]). Notwithstanding, accounts of such impacts in Vietnam are limited.

The diversity and activities of earthworms as one of the most important soil biotas influence the physical, chemical, and biological properties of soils [22,23]. Their physical movement creates soil pores which ease nutrient and water dynamic in the soils. As recyclers of organic materials, earthworms facilitate microorganisms such as fungi and bacteria to undertake further decomposing process [24]. Through these activities, earthworms influence soil health and the provision of ecosystem services [25]. The population and diversity of earthworm species vary across land habitats due to variation in soil moisture, soil temperature, soil properties, the abundance of surface litter, vegetation types, land use management, and human interventions [20,26-30]. Earthworms are thus sensitive to change in land use. In general, earthworm diversity is reduced in habitats with more intensive anthropogenic interventions [23,31].

Here, we describe the results of a study on earthworm diversity in natural forests and different land uses in two communes of Quang Nam province, South Central Coast region of Vietnam. The two communes are within the buffer zones of the Song Thanh Nature Reserve, one of the main reserves within the Central Annamites mountains, and parts of 
main watersheds in the region. In both communes, the conversion of natural forests into shifting cultivations and agricultural systems, such as agroforestry and annual croplands, has been taking place for decades. The purpose of the study was to compare the diversity of earthworm species among natural forest and different land uses to investigate the impact of forest conversion and to recommend necessary measures related to earthworm conservation to maintain soil health and ecosystem functions in the two buffer-zone communes.

\section{Material and Methods}

\subsection{Study Sites}

The study was conducted in Phuoc My commune of Phuoc Son district and Ta Bhing commune of Nam Giang district, Quang Nam province $\left(15^{\circ} 35^{\prime} 0^{\prime \prime} \mathrm{N}-107^{\circ} 55^{\prime} 0^{\prime \prime} \mathrm{E}\right)$, South Central Coast of Vietnam (Figure 1a). The two communes are within the buffer zones of Song Thanh Nature Reserve and parts of main watersheds in South Central Coast region which supply water for several cities including Da Nang as the biggest city in Central Vietnam. For example, Phuoc My is part of Dak Mi watershed (Figure 1b), while Ta Bhing is part of $\mathrm{Vu}$ Gia-Thu Bon as a bigger watershed [32]. Phuoc My is situated at 223-446 m above sea level while Ta Bhing is approximately $100 \mathrm{~m}$ above sea level. Both communes are mountainous with flat areas concentrated at the feet of the mountains, along riverbanks.

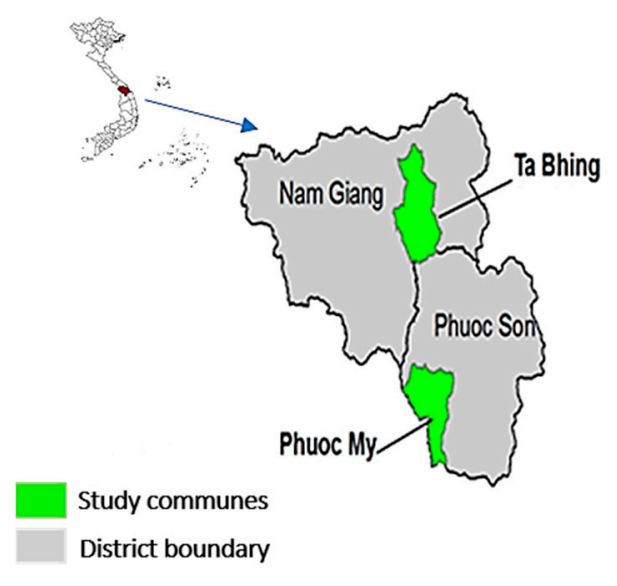

(a)

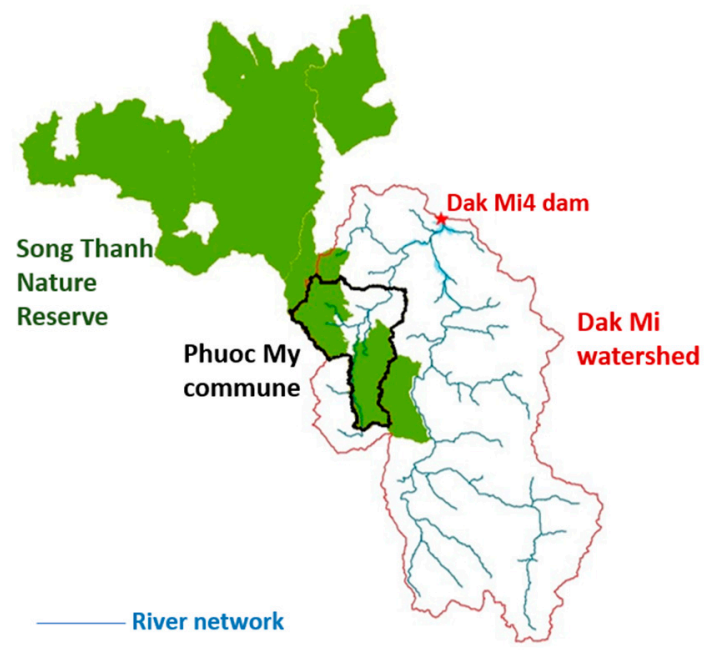

(b)

Figure 1. (a) Location of Phuoc My and Ta Bhing communes as study sites in Quang Nam province of Vietnam, (b) the boundary of Song Thanh Nature Reserve and Dak Mi watershed.

The two communes have a tropical monsoon climate. The annual rainfall is about $2650 \mathrm{~mm}$ in Phuoc My and $2300 \mathrm{~mm}$ in Ta Bhing [33]. In both communes, the rainy season usually peaks between September and November, and the dry season lasts from January until March. The highest temperature is usually recorded between May and July. The two communes have similar soil physical and chemical properties, dominated by sandy-loam and sandy-clay-loam textures [33].

Phuoc My has a smaller land size, but it has a larger area of rich natural forest than Ta Bhing in 2016. The total area of medium, poor, and regenerated natural forests accounts for $21 \%$ and $41.5 \%$ of the total land size in Phuoc My and Ta Bhing respectively. Land cover in the two communes has been classified into eleven types [16]. The area of each land cover in the two communes are described in Table A1.

\subsection{Land-Use History}

In both communes, massive conversion of natural forests took place more than 20 to 30 years ago [16]. Over the past two decades, natural forests have regenerated in some 
areas of the communes, thanks to enhanced protection efforts by the local authorities. Planted forests have become popular in the past decade, especially the short-rotation (3-4 year) of Acacia (mainly the hybrid Acacia mangium $x$ auriculiformis) plantation for pulp and paper. Two types of agroforestry have developed in the two communes: a taungya or temporary agroforestry in which annual crops such as cassava or maize become intercrops in young planted forests, usually in the first 1-2 years after tree planting before tree canopy closure; and more permanent agroforestry in which timber tree species, such as Melia azedarach, Vernicia montana, or Ficus racemosa, or fruit trees such as Dimocarpus longan, were intercropped with annual crops such as peanut, beans, or cassava. In sloping lands, agroforestry practices with rows of trees and rows of pineapple to limit soil erosion also existed.

\subsection{Sample Plots by Habitat}

The earthworm's observations were carried out in seven land cover types (hereafter called habitats). Three represent habitats with less anthropogenic interventions namely natural forests, regenerated forests, and grasslands (hereafter referred to as 'natural habitats'); and four with more intensive anthropogenic interventions namely planted forests, agroforestry, mixed annual crops, and home gardens (hereafter referred to as 'human-disturbed habitats'). Among the four, the most frequent and intensive anthropogenic interventions occurred in mixed annual crops and home gardens.

In total, we took 28 and 53 sample plots from the different habitats in Phuoc My and Ta Bhing commune respectively. More sample plots were taken in natural and regenerated forests to anticipate a possibility of higher species diversity in those habitats. Although both communes have similarities in many of the factors that can influence earthworm diversity such as climate condition, soil properties, and landcover types, we took sample plots in both communes, but more samples plots in Ta Bhing than Phuoc My merely for time and resource efficiency. Most of the local assistants involved in the sampling activities in both communes were from Ta Bhing. The aim was to have replications from both communes, not to compare earthworm diversity between the two communes. The number of sample plot by habitat in the two communes are given in Table A2. Figure 2 illustrates the vegetation covers and types in the selected habitats.
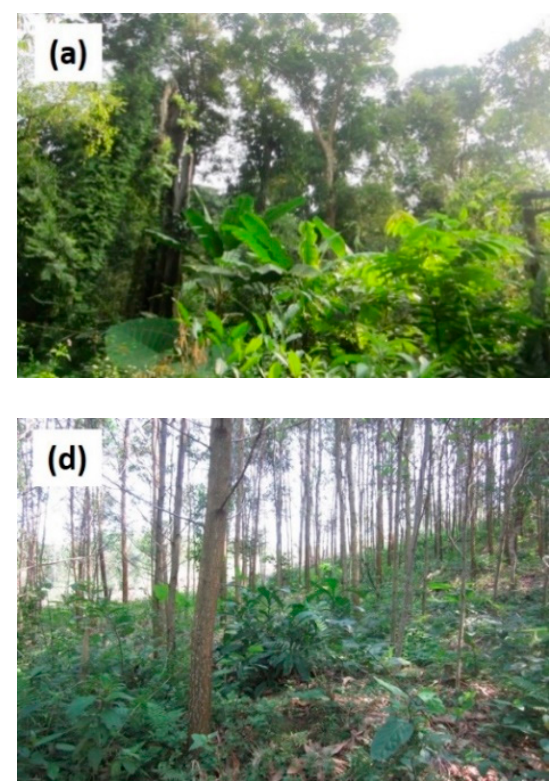
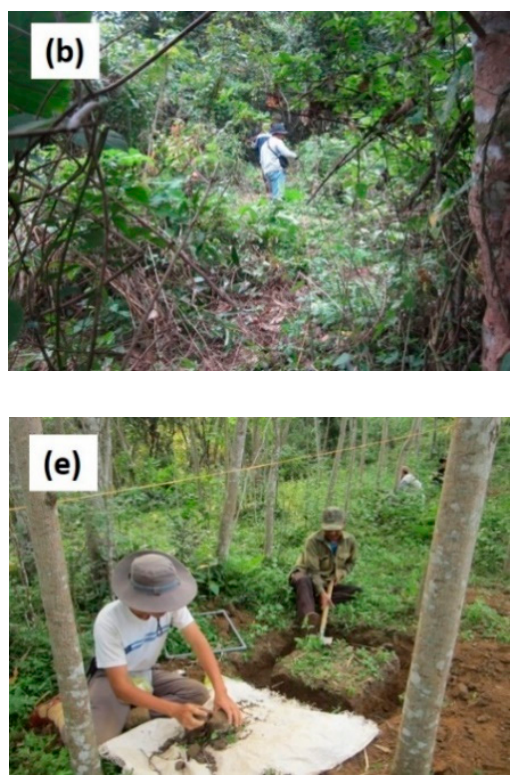

Figure 2. Cont.
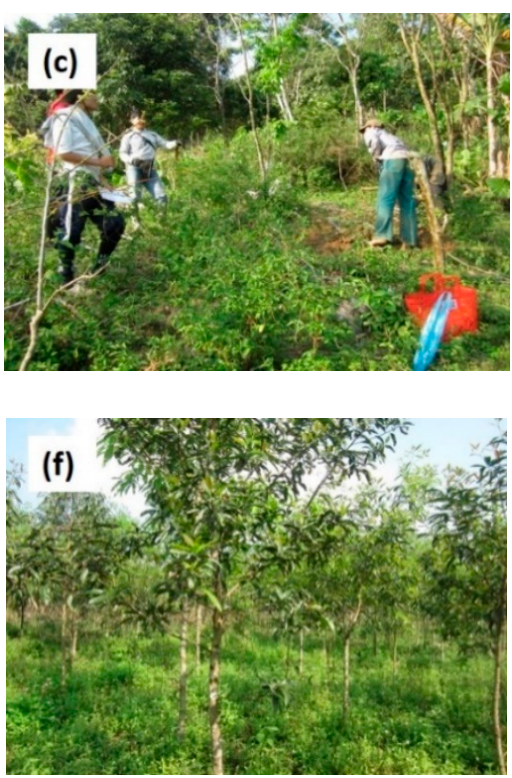

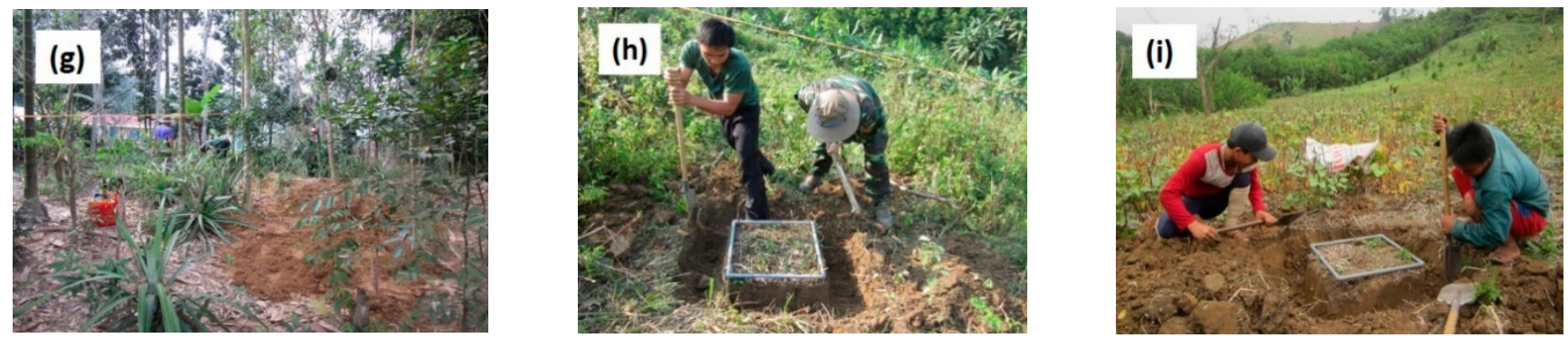

Figure 2. Vegetation cover and types in (a) natural forest, (b) regenerated forest, (c) agroforestry, (d) plantation of Acacia mangium x auriculiformis, (e) plantation of Melia azedarach, (f) plantation for Machilus odoratissima Nees, (g) home garden, (h) grasslands, and (i) upland annual crops.

\subsection{Identification of Earthworm Species}

Following [34], at each sample plot, earthworm specimens were collected from a $50 \mathrm{~cm} \times 50 \mathrm{~cm}$ soil block of $30 \mathrm{~cm}$ depth (please see Figure 2e,h,i). A $50 \mathrm{~cm} \times 50 \mathrm{~cm}$ supporting frame and a woody measure of $30 \mathrm{~cm}$ long were used to ensure identical surface areas and thicknesses of all soil blocks. The specimens were collected by carefully segregating the soils per $10 \mathrm{~cm}$ soil depth. All specimens were stored in cloth bags to keep them alive for further treatments in the laboratory.

To facilitate species identification, all earthworms were separated from soils by cleansing with water. They were subsequently immersed in liquid containing $4 \%$ formalin for 6-12 h. Thereafter, all earthworms were transferred to fresh liquid of $4 \%$ formalin for long-term storage and morphological studies. We investigated morphological features of collected earthworms, such as intestinal caeca (presence and shape), male pores (presence of copulatory pouches), genital markings (type, location, and number), spermathecal pores (location, number, and type), septa (thin, thick or absent), and additional characteristics such as prostomium (probilobous, epilobous or tanylobous), first dorsal pore (location), intestinal origin, last heart, ovaries, and testes. Earthworm samples were scrutinized using stereo microscope Motic DM143-FBGG-C (Motic Company, Hongkong) with drawing tube and camera attached to the monitor. All specimens were compared and identified using original papers as described in [35-43]. All specimens with different morphological characters compared to all known species were named using their genera and sp. 1,2, and so on. For biomass measurement, we used paper tissues to remove all liquids (formalin, water) and cast from the preserved earthworms before weighting using the electronic weight Sartorius GM612.

\subsection{Indicators for Earthworm Dominance and Diversity}

We used seven indicators to assess the dominance, density, and diversity of earthworm species. Following [34], five indicators represent dominance and density, namely density and biomass per soil layer, quantity and biomass dominance, and occurrence frequency. Two indicators, the Shannon-Wiener index [44] and similarity index [45], measure the level of diversity of earthworm species within habitat and similarity in species composition among habitats, respectively. For the similarity index, we omitted the sub-species component in the calculation. The seven indicators are described in Table A3.

\subsection{Aboveground Litter Biomass as A Covariate}

In this study, we focused on the impact of conversion from natural to human-disturbed habitats on earthworm diversity. Notwithstanding, to consider the effect of aboveground plant litter biomass on earthworm density (e.g., [21,46,47]), we used the annual production rate of aboveground plant litter biomass (hereafter referred to as "annual litter production") (Table 1) as a covariate when comparing indicators among habitats. Due to a lack of data, we estimated the annual litter production from the annual production rate of aboveground 
plant biomass (hereafter referred to as "annual biomass production") of the habitats. We used a factor of 0.49 calculated from [48] for the biomass-litter conversion and assumed the same factor applies for all habitats. The biomass production data were obtained from [16] that estimated the standing aboveground plant biomass of all habitats in the two study communes, except NF and AF, under different ages using the Rapid Carbon Stock Appraisal approach [49]. The annual biomass production was calculated from the standing biomass and plot ages, assuming a constant biomass production across the year. We used an annual litter production of 9.3 ton $\mathrm{ha}^{-1}$ year $^{-1}$ from [50] for NF and $2.4 \pm 0.4$ ton ha ${ }^{-1}$ year $^{-1}$ calculated from [51] for AF. The earthworm and plant biomass assessment were not conducted using the same sample plots. Therefore, to create a variation of annual litter biomass among earthworm sample plots, we used random numbers from a uniform distribution to generate higher or lower litter biomass by a maximum of one standard error from the mean. We applied this for all habitats except for NF that lacks input data on the standard error of the mean.

Table 1. Annual production of aboveground plant litter biomass by habitat (source: calculated from [16]).

\begin{tabular}{cccc}
\hline \multirow{2}{*}{ Habitat } & \multirow{2}{*}{ Number of Sample Plots } & \multicolumn{2}{c}{${\text { Litter Production (ton } \mathbf{~ h a ~}^{-\mathbf{1}} \text { year }}^{\mathbf{- 1}}$ ) } \\
\cline { 3 - 4 } & & Average & SE \\
\hline Regenerated Forest (RF) & 4 & 5.8 & 0.26 \\
Grassland (GL) & 18 & 0.7 & 0.05 \\
Planted Forest (PF) & 37 & 4.4 & 0.35 \\
Upland Crops (UC) & 11 & 2.7 & 0.45 \\
Home Garden (HG) & 8 & 3.4 & 0.87 \\
\hline
\end{tabular}

\subsection{Statistical Analysis}

We used the IBM SPSS Statistics version 23 to test the difference in earthworm indicators among habitats using one-way analysis of covariance (ANCOVA). For the statistical test, we assumed an independency among sample plots. For all data and statistical analysis, we combined the earthworm data from the two study communes and the difference between the two communes was not investigated. All graphs were produced using the Microsoft Excel.

\section{Results}

\subsection{Species Occupancy by Habitat}

A total of 25 earthworm species from 3 families and 6 genera were found in the two study communes. Of these, 23 species belong to the Megascolecidae family and 17 species to the Amynthas genus. Only one genus and one species were found in each of the other two families, Moniligastridae and Rhinodrilidae. Seven out of the 25 species, namely Pontoscolex corethrurus, Amynthas aspergillum, Amynthas divitopapillatus, Amynthas modiglianii, Amynthas sp.1, Metaphire houlleti, and Polypheretima taprobanae were omnipresent. However, only P. corethrurus dominated the habitats, except in NF and RF. The average frequency of occurrence of this species in human-disturbed habitats was $87 \%$. Based on the occurrence frequency, P. corethrurus is classified as rare species in NF and uncommon species in RF. In $\mathrm{NF}$, only Drawida beddardi had occurrence frequency above $25 \%$. The occurrence frequency of earthworm species by habitat is given in Table A4.

\subsection{Earthworm Density and Biomass by Habitat}

The NF tends to have a lower earthworm density compared to other habitats (Figure 3a). However, no significant difference ( $p$-value $>0.05$ ) was found among habitats due to large standard errors. In terms of biomass, the natural habitats had higher earthworm biomass compared to human-disturbed habitats ( $p$-value $<0.001$ ), likely because of the larger earthworm's physical size. The ratio between earthworm biomass and density was much lower in the human-disturbed habitats $(p$-value $<0.001)$ with an average of $0.73 \pm 0.14 \mathrm{~g}$ per 
individual compared to $1.62 \pm 0.23 \mathrm{~g}$ per individual in natural habitats. Related to quantity and biomass dominance, $P$. corethrurus was much more dominant in human-disturbed than natural habitats $(p$-value $<0.01)$ particularly due to extremely low dominance in NF (Figure $3 \mathrm{~b}$ ). The quantity and biomass dominance of all species by habitat is provided in Table A5.

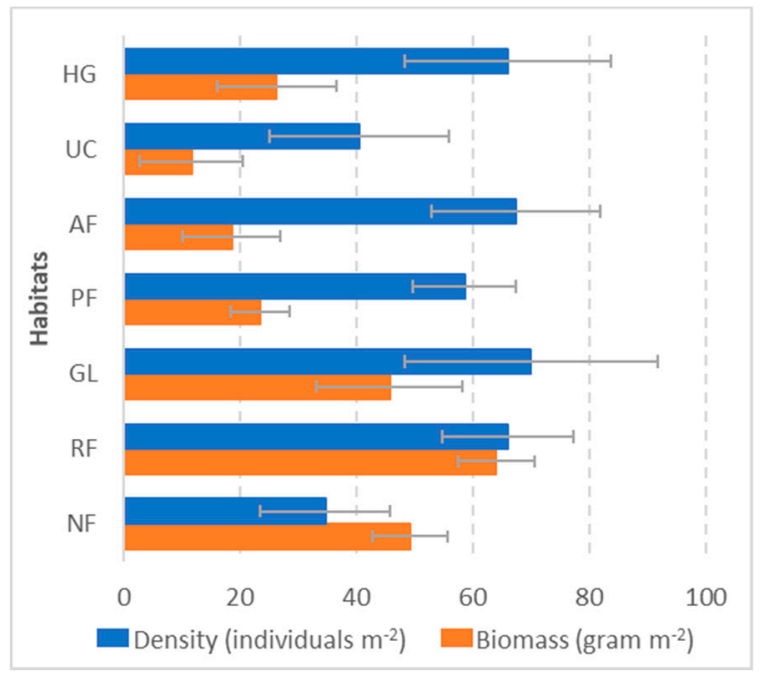

(a)

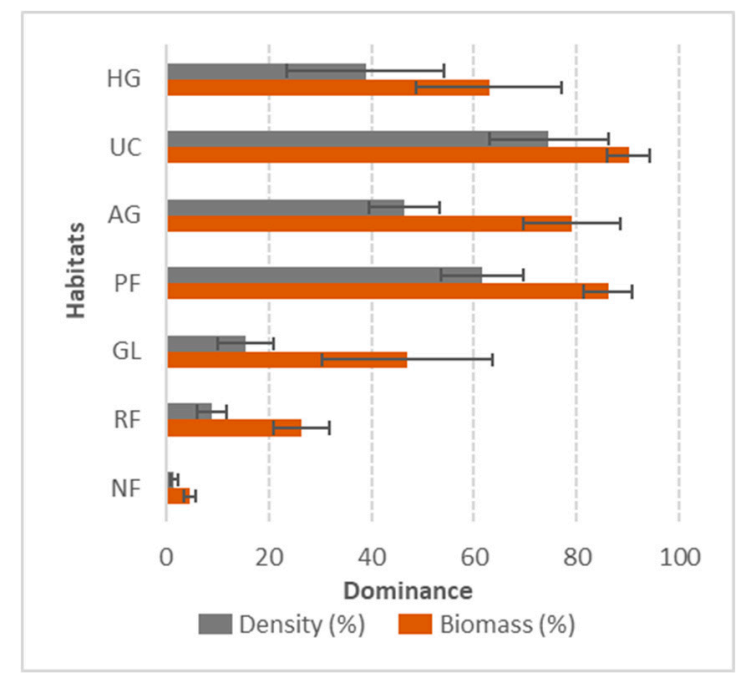

(b)

Figure 3. (a) Earthworm density and biomass and (b) quantity and biomass dominance of P. corethrurus.

\subsection{Earthworm Density and Biomass by Soil Depth}

Both the natural and human-disturbed habitats generally had higher density of earthworm in the first $10 \mathrm{~cm}$ than deeper soil layers ( $p$-value $=0.001$ ) (Figure $4 \mathrm{a})$. However, the decrease in the density by soil layer was more pronounced in natural habitats, especially in NF and RF, than human-disturbed habitats. In terms of biomass, both natural and human-disturbed habitats generally had comparable earthworm biomass in the first two soil layers, and lower biomass ( $p$-value $<0.002)$ in the $20-30 \mathrm{~cm}$ soil depth (Figure $4 \mathrm{~b}$ ).

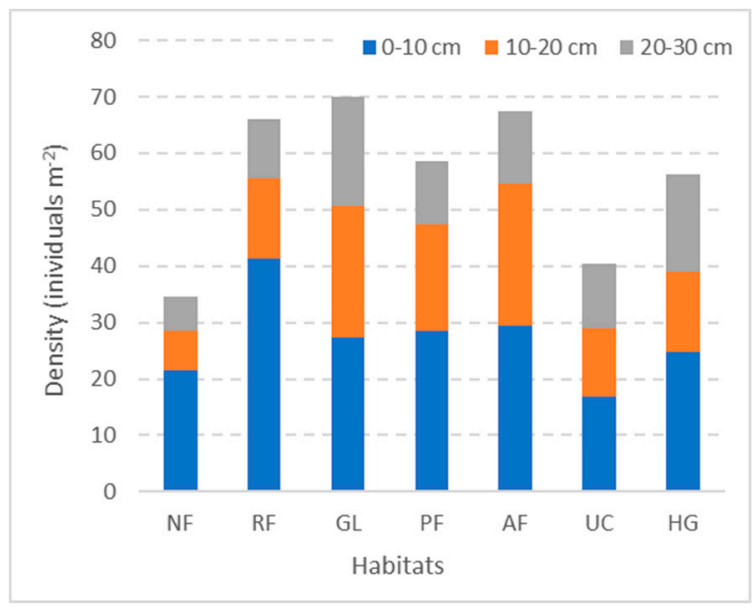

(a)

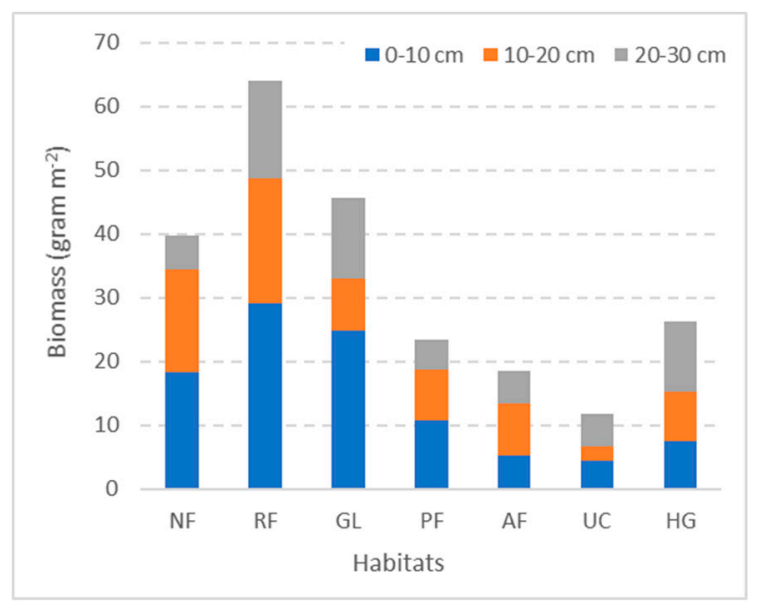

(b)

Figure 4. Earthworm (a) density and (b) biomass by soil depth. 


\subsection{Species Diversity and Similarity Among Habitats}

The natural habitats had a higher species diversity than the human-disturbed habitats ( $p$-value $<0.001$ ) (Figure 5a). The weak dominance of $P$. corethrurus especially in NF and $\mathrm{RF}$ was associated with higher species diversity. Among the human-disturbed habitats, the number of earthworm species found in UC and HG was equal, however, the ShannonWiener index of UC was much lower due to the strong dominance of few species.

The NF and RF had a similar earthworm species composition (Figure 5b). Among the four human-disturbed habitats, only UC and HG had a level of similarity. In general, the species composition in natural and human-disturbed habitats was different, except between RF and AF.

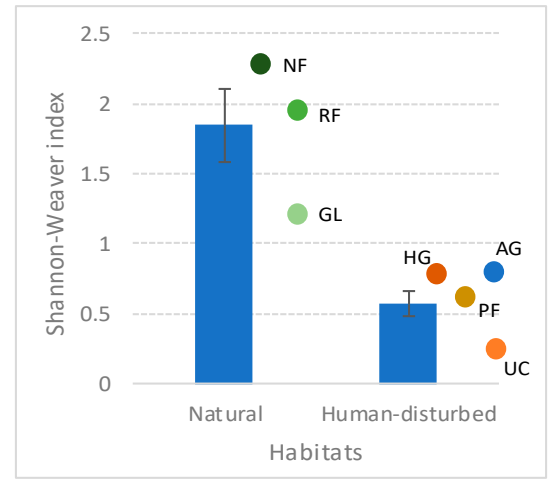

(a)

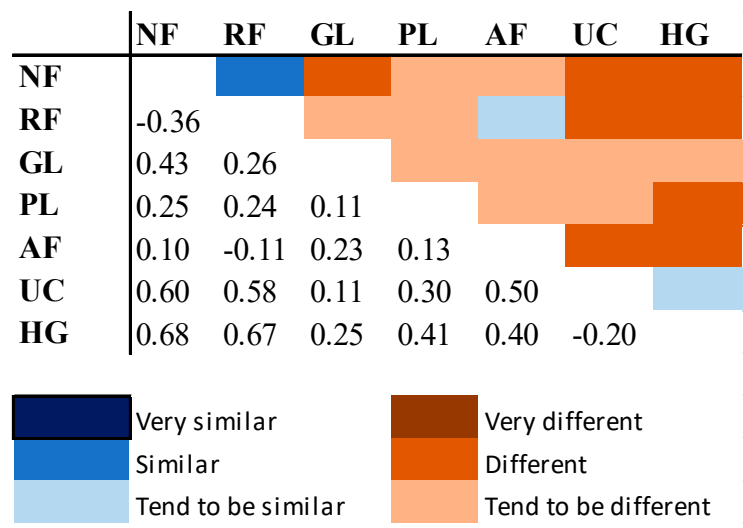

(b)

Figure 5. (a) Shannon-Wiener and (b) similarity index among habitats.

\subsection{Variation among Types of Planted Forests}

The Acacia plantation had more diverse earthworm species than Melia or Machilus plantation (Table 2). However, P. corethrurus was less dominant in Melia plantation because two other species, Amynthas aspergillum, and Metapheretima tiencanhensis, had an occurrence frequency above $25 \%$. Also, earthworms in Melia plantation had a higher biomass and density ratio that reached $1.58 \mathrm{~g}$ per individual, compared to 0.3 and $0.5 \mathrm{~g}$ per individual in Acacia and Machilus plantations, respectively.

Table 2. Earthworm indicators comparing three types of planted forest.

\begin{tabular}{cccc}
\hline Earthworm Indicators & Acacia & Melia & Machilus \\
\hline No. of sample plots & 15 & 5 & 4 \\
No. of species & 13 & 7 & 9 \\
Frequency of occurrence of P. corethrurus (\%) & 97 & 72 & 100 \\
No. of species with occurrence frequency $\geq 25 \%$ & 1 & 3 & 2 \\
Density (individuals m $^{-2}$ ) & 80 & 17 & 59 \\
Biomass (gram m $^{-2}$ ) & 23 & 27 & 27 \\
Shannon-Wiener index & 0.48 & 0.95 & 0.5 \\
\hline
\end{tabular}

\section{Discussion}

\subsection{Earthworm Diversity in Agroforestry}

In our study, among the human-disturbed habitats, higher earthworm diversity was found in tree-based farming systems like AF and PF. Other studies [52-57] reported similar evidence. Improved micro-climate, e.g., lower soil temperature and higher soil humidity, minimum plot management practices such as tillage, and a higher supply of organic matter from above- and below-ground litter all generate higher earthworm diversity in tree-based systems $[58,59]$. These factors also create contrast in earthworm diversity between areas nearby and far from the trees within $\mathrm{AF}$, for example between tree row and crop alley in 
the alley-cropping system. In addition, minimal application of chemical inputs such as fertilizer and pesticide contribute to generating higher earthworm diversity within tree rows $[58,60]$. The variation in micro-climate and plot management practices also influence earthworm density. For example, in poplar AF in Canada, the average earthworm density within tree row was 182 individuals $\mathrm{m}^{-2}$, compared to 117 and 95 individuals $\mathrm{m}^{-2}$ within the crop alley at two and six meters away from tree row, respectively [60]. In our study, some of the observed AFs were alley cropping, and others had scattered trees over the plots. In both cases, soil blocks for earthworm observation were taken relatively close to the trees, to avoid causing damage to annual crops. This likely explains the comparable earthworm diversity between $\mathrm{AF}$ and PF. AF can become a solution if larger areas of annual crops are needed without further converting NF or RF which otherwise will further decline the ecosystem health and functions in the two communes.

\subsection{Potential Impact of P. corethrurus Dominance}

The dominance of $P$. corethrurus in human-disturbed habitats has also been reported in other studies especially in tropical areas, e.g., see review in [61]. The species was exotic to Vietnam and initially inhabited hilly areas of the country $[62,63]$. Nowadays, it has a large distribution area including in the coastal areas of the country [64]. Compared to other exotic species which deliberately or inadvertently colonize new habitats, P. corethrurus has a high survival rate thanks to its tolerance to a range of biotic and abiotic environment [24,65]. Many other species either fail to survive or survive but not invasive [66].

P. corethrurus could bring favorable or unfavorable impacts to new habitats, although generally considered harmful to the environment and native species. As summarized in [61], as favorable impacts, the species could for example stimulate nutrient release in soil and enhance plant's resistance to phyto-parasitic nematodes. However, as unfavorable impacts, it can create soil compaction and alter biogeochemical processes to affect plants, native earthworms, and microbial communities. P. corethrurus can compact the soils through its feeding activity which accumulates small soil aggregates. In the absence of intervention from other soil biota, the small aggregates will progressively transform into larges aggregates and become compact $[67,68]$. In addition, layers of cast produced by this species on the soil surface, can turn into thick crust preventing water and air penetration to the soils [69]. The role of P. corethrurus in increasing soil bulk density and reducing soil porosity were reported in (e.g., $[52,67,70,71])$. Due to the unfavorable impacts, the presence and dominance of $P$. corethrurus have been considered as an indicator for soil health and level of disturbance to ecosystem and ecosystem services [72].

Our study shows the dominance of $P$. corethrurus in human-disturbed habitats namely PF, AF, UC, and HG which occupy about $17 \%$ and $20 \%$ of total land area in Phuoc My and Ta Bhing commune, respectively. These land uses potentially expand in the two communes driven by augmenting population and livelihood pressure. The two communes are therefore under a serious threat of further loss of earthworm diversity and stronger dominance of $P$. corethrurus, which can further reduce their ecosystem health and functions. Under the increasing dominance of the cosmopolitan species, the soil porosity and ecosystem functions in the two communes will mainly rely on tree roots. Therefore, tree-based farming systems such as AF are preferable to reconcile livelihood and provision of ecosystem services. Moreover, this land-use system generally has higher earthworm diversity than sole annual crop systems. Also, there is a need to select more suitable tree species for PF because of its popularity as land use in the two communes. Although Acacia is currently the most popular type of PF supported by local pulp and paper industries, Melia is worth to get further attention and research due to the lower dominance of $P$. corethrurus in the PF using this tree species. Based on the unpublished data as part of a study by [16], Melia in the communes likely had a superficial rooting system (Figure 6) which can create microand macropores in superficial soil layers through its coarse and fine roots. It has a root shallowness index of 0.83, higher than Acacia (0.69), and Machilus (0.63). The index measures the ratio of cross-sectional areas of horizontal and all proximal roots. Horizontal proximal 
roots are defined as those with an angle of less than 45 degrees relative to the soil surface. The number of replications in the root study was however limited, only involved three different trees, and worth for further investigation. Therefore, promoting this species in the communes can contribute to maintaining soil porosity with less dominance of $P$. corethrurus. Also, in terms of topographical, soil, and climate condition, Melia is suitable for the two study communes [16].

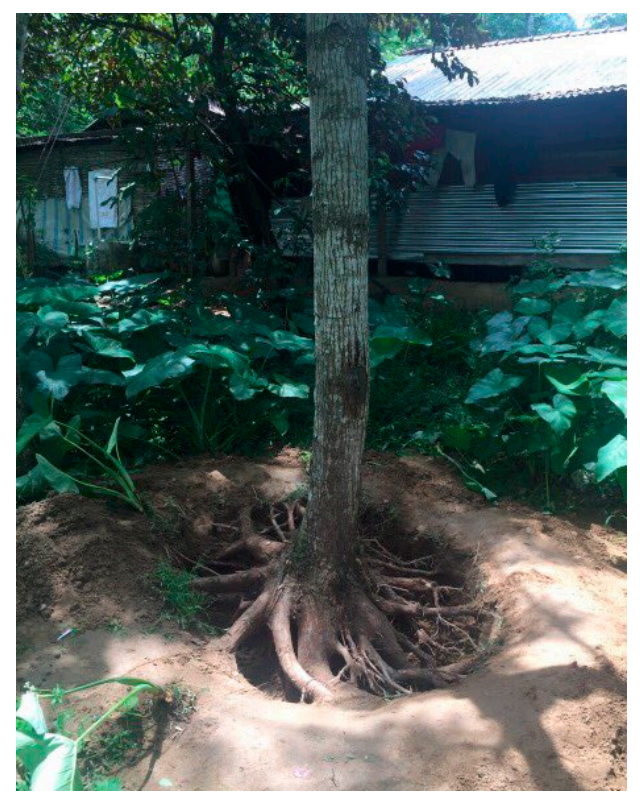

(a)

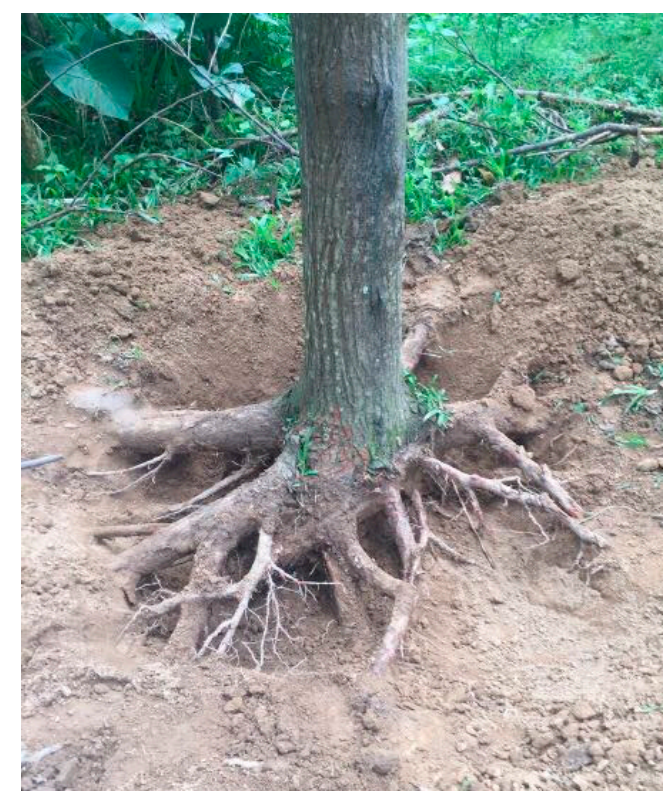

(b)

Figure 6. Distribution of proximal roots of Melia azedarach in (a) home garden and (b) forest plantation.

\subsection{Caveats in Assessing Earthworm-Habitat Linkage}

In this study, we could demonstrate that natural- and human-disturbed habitats have different levels of earthworm density and diversity. However, we could not do in-depth analysis on the effect of environmental factors to the differences among habitats due to lack of data such as on soil physical and chemical properties by sample plot. Several studies utilized the results of correlation analysis between earthworm and soil indicators for further purpose, for example considering earthworm density or diversity as proxy for levels of soil quality or pollution (e.g., [73-75]). Some of these studies also assessed the level of metal pollution in the soils and in the earthworm tissue or casts [74,76]. Further researches on earthworm in the two study communes are therefore necessary and should focus on assessing the impacts of soil and terrestrial conditions on the earthworm density and diversity. The terrestrial condition includes type and abundance of plant litter biomass. The researches can also associate the results of soil-earthworm analysis with the potential role of earthworm in the two study communes on watershed service.

\subsection{Further Studies for the Unidentified Species}

In our study, seven out of nine unidentified species belong to Amynthas genus. The seven species were mostly found in NF and RF with only Amynthas sp. 1 was an omnipresent inhabitant of all observed habitats. Also, Amynthas sp. 1 had a relatively high occurrence frequency in human-disturbed habitats such as AF and HG. Compared to the eleven identified species of Amynthas genus, three out of the eleven were omnipresent inhabitants, namely Amynthas aspergillum, Amynthas divitopapillatus, and Amynthas modiglianii, while the other eight were inhabitants of some habitats only, or one habitat such as the case for Amynthas wui. Therefore, earthworm species of Amynthas genus likely have different land colonization patterns or perhaps levels of resistance to the new habitat's condition. 
The seven unidentified species have different external and internal morphological features compared to 115 earthworm species of Amynthas genus that have been identified from past studies across regions in Vietnam. To ascertain if all the seven species are new to the country, a comparison with four species of the genus Amynthas Kinberg, 1867 recently identified in the southeastern part of the country [77] is however necessary. Further studies can also compare morphological features of the unidentified species with those of Amynthas species identified in other countries. For example, earthworm species of the genus Amynthas Kinberg, 1867 of family Megascolecidae, the same family with Amynthas earthworms found in our study, had been known as common inhabitants of natural forests in the northern part of Laos [78]. Recently, three new earthworm species belonging to this genus were found in that part of the country [78]. Apart from morphological features, further studies should compare living habitat and land colonization pattern between the unidentified and known Amynthas species. Similar efforts are necessary for the unidentified species of other genus found in the current study, namely one each of Metaphire and Polypheretima genus of the Megascolecidae family.

\section{Conclusions}

The conversion of natural forests to different land uses in the two buffer-zone communes of Song Thanh Nature Reserve had reduced earthworm diversity which can substantially affect soil health and ecosystem functions in the two communes. Also, among the identified species, $P$. corethrurus was omnipresent and largely dominated human-disturbed habitats. The dominance of this species can bring unfavorable impacts such as soil compaction and continuous threat to native earthworm species. This will further affect soil porosity and related ecosystem functions and reduce the role of the two communes to the nature reserve and watershed of which the two communes are part of. The area of human-disturbed habitats in the two communes potentially expand driven by augmenting population and livelihood pressures. This will lead to further loss of earthworm diversity and stronger dominance of $P$. corethrurus. To avoid the further decline of earthworm diversity and rampant expansion of $P$. corethrurus in the two study communes, protection of the remaining natural and regenerated forests is urgent, and tree-based farming systems such as agroforestry should be promoted to reconcile earthworm conservation and local livelihoods. The results of this study enrich current limited knowledge on impacts of forest and land use conversion on earthworm density and diversity in Vietnam. Furthermore, the results can generate stronger concerns with respect to the degradation of belowground diversity in the country and call attention to the urgent need for strengthened forest protection efforts.

Author Contributions: Conceptualization, R.M. and M.v.N.; data curation, R.M., S.V.H., V.M.D., N.B.T.D., A.D.N., D.H.L., D.T.T.H., and M.v.N.; formal analysis, S.V.H., V.M.D., N.B.T.D., A.D.N., D.H.L., and D.T.T.H.; investigation, S.V.H., V.M.D., N.B.T.D., A.D.N., D.H.L., and D.T.T.H.; methodology, S.V.H., V.M.D., N.B.T.D., A.D.N., D.H.L., D.T.T.H., and M.v.N.; supervision, M.v.N.; writingoriginal draft, R.M., S.V.H., V.M.D., N.B.T.D., A.D.N., D.H.L., and D.T.T.H.; writing-review \& editing, R.M., S.V.H., and M.v.N. All authors have read and agreed to the published version of the manuscript.

Funding: This research was funded by the United States Agency for International Development (USAID) to assess the livelihoods and ecological conditions of buffer-zone communes in Song Thanh Nature Reserve, Quang Nam province, and Phong Dien Nature Reserve, Thua Thien Hue province, grant number TF069018. The APC was funded by the same project.

Institutional Review Board Statement: Not applicable.

Informed Consent Statement: Not applicable.

Data Availability Statement: Data available in a publicly accessible repository.

Acknowledgments: We thank Le Tho Son, Nguyen Minh Quang, and Dao Van Chuong from the Vietnam National University of Forestry for their great contribution in the field inventory; Delia C. Catacutan, Nguyen Quang Tan, Do Trong Hoan, Nguyen Mai Phuong, Kurniatun Hairiah, and Pham 
Thanh Van from the World Agroforestry (ICRAF) and Do Hoang Chung from Thai Nguyen University of Agriculture and Forestry, for their great help in field inventory and valuable inputs during data analysis and manuscript writing. We also thank valuable comments from three anonymous reviewers.

Conflicts of Interest: The authors declare no conflict of interest. The funders had no role in the design of the study; in the collection, analyses, or interpretation of data; in the writing of the manuscript, or in the decision to publish the results.

\section{Appendix A}

Table A1. Land cover types and areas in the study communes in 2016.

\begin{tabular}{|c|c|c|c|c|}
\hline \multirow{2}{*}{ Land Cover Types } & \multicolumn{2}{|c|}{ Phuoc My } & \multicolumn{2}{|c|}{ Ta Bhing } \\
\hline & $\mathrm{Ha}$ & $\%$ & $\mathrm{Ha}$ & $\%$ \\
\hline Natural forest-rich & 7788 & 61.4 & 5766 & 36.5 \\
\hline Logged over natural forest-medium & 1447 & 11.4 & 5307 & 33.6 \\
\hline Logged over natural forest-poor & 492 & 3.9 & 917 & 5.8 \\
\hline Regenerated natural forest & 704 & 5.6 & 328 & 2.1 \\
\hline Planted forest & 798 & 6.3 & 1687 & 10.7 \\
\hline Agroforestry & 267 & 2.2 & 149 & 1.0 \\
\hline Home garden & 28 & 0.2 & 56 & 0.4 \\
\hline Grasslands & 641 & 5.1 & 774 & 4.9 \\
\hline Mixed annual crops & 390 & 3.1 & 693 & 4.4 \\
\hline Paddy rice & 63 & 0.5 & 52 & 0.3 \\
\hline Settlement, built up areas & 59 & 0.5 & 89 & 0.6 \\
\hline Total (ha) & 12,677 & & 15,818 & \\
\hline
\end{tabular}

Data source: [16].

Table A2. Selected habitats for earthworm observations and number of sample plots.

\begin{tabular}{|c|c|c|c|c|}
\hline \multirow{2}{*}{ Habitat } & \multirow{2}{*}{ Tree Cover (\%) } & \multicolumn{2}{|c|}{ No. of Sample Plots } & \multirow{2}{*}{ Vegetation in Both Communes } \\
\hline & & PM * & TB * & \\
\hline Natural forest (NF) & $>60$ & 5 & 10 & $\begin{array}{c}\text { Fagaceae, Lauraceae, Meliaceae, Moraceae, } \\
\text { Euphorbiaceae, Dipterocarpaceae, Sapindaceae }\end{array}$ \\
\hline Regenerated forest (RF) & $10-30$ & 5 & 10 & $\begin{array}{c}\text { Bambosoideae such as Bambusa natans, } \\
\text { Dendrocalamus patellaris, Neohouzeauna dullooa, } \\
\text { and shrubs }\end{array}$ \\
\hline Grassland (GL) & $<10$ & 1 & 3 & Shrub and grass \\
\hline Planted forest (PF) & Young: <30, mature: $>30$ & 9 & 15 & $\begin{array}{l}\text { In Phuoc My: Acacia ( } 5 \text { sample plots), Machilus } \\
\text { odoratissima Nees (4); in Ta Bhing: Acacia (10), Melia } \\
\text { azedarach (5). In both communes, Acacia variety is } \\
\text { mostly the hybrid Acacia mangium x auriculiformis }\end{array}$ \\
\hline Agroforestry (AF) & Young: <30, mature: >30 & 4 & 5 & $\begin{array}{c}\text { Acacia-based with cassava, banana, or herbal } \\
\text { plants (4), Melia-based with banana or cassava (2), } \\
\text { agroforestry with mixed tree species such as } \\
\text { Vernicia montana, Ficus racemose, Dimocarpus longan } \\
\text { and annual crops such as cassava, banana, } \\
\text { vegetables (3) }\end{array}$ \\
\hline $\begin{array}{l}\text { Upland annual crops } \\
\text { (UC) }\end{array}$ & $<10$ & 3 & 5 & Key crops such as paddy rice, maize, and cassava \\
\hline Home garden (HG) & $>30$ & 1 & 5 & $\begin{array}{l}\text { Mostly diverse vegetable, annual crop and fruit } \\
\text { trees such as mango, jackfruit, and longan trees }\end{array}$ \\
\hline
\end{tabular}

* PM: Phuoc My commune, TB: Ta Bhing commune. 
Table A3. Indicators for earthworm's dominance and diversity.

\begin{tabular}{|c|c|c|c|c|}
\hline No & Indicators & Formula & Unit & Remark \\
\hline 1 & Density per soil layer & $\frac{n_{\mathrm{ijk}}}{N_{\mathrm{jk}}} \times 4$ & Individual $\mathrm{m}^{-2}$ & $\begin{array}{c}\mathrm{n}_{\mathrm{ijk}}=\text { number of individual of species } \mathrm{i} \text { in soil block } \mathrm{k} \\
\text { layer } \mathrm{j} \\
\mathrm{N}_{\mathrm{kj}}=\text { total number of individuals from all species in } \\
\text { soil block } \mathrm{k} \text { layer } \mathrm{j}\end{array}$ \\
\hline 2 & Biomass per soil layer & $\frac{b_{\mathrm{ijk}}}{N_{\mathrm{jk}}} \times 4$ & $\mathrm{~g} \mathrm{~m}^{-2}$ & $b_{i j k}=$ total biomass of species $i$ in soil block $k$ layer $j$ \\
\hline 3 & Quantity dominance & $\frac{n_{i}}{N} \times 100 \%$ & $\%$ & $\begin{array}{l}\mathrm{n}_{\mathrm{i}}=\text { number of individuals of species } \mathrm{i}, \mathrm{N}=\text { total } \\
\text { number of individuals of all species in the habitat }\end{array}$ \\
\hline 4 & Biomass dominance & $\frac{b_{i}}{B} \times 100 \%$ & $\%$ & $\begin{array}{c}\mathrm{b}_{\mathrm{i}}=\text { total biomass of species } \mathrm{i}, \mathrm{B}=\text { total biomass of all } \\
\text { species in the habitat }\end{array}$ \\
\hline 5 & Occurrence frequency & $\frac{S_{i}}{S} \times 100 \%$ & $\%$ & $\begin{array}{c}\mathrm{s}_{\mathrm{i}}=\text { number of sample plots having species } \mathrm{i}, \mathrm{S}=\text { total } \\
\text { number of sample plots for the habitat. Range of } \\
\text { values: }>75 \%=\text { very common species, }>50-75 \%= \\
\text { common species, } 25-50 \%=\text { uncommon species, }<25 \%= \\
\text { rare species }\end{array}$ \\
\hline 6 & Shanon- Wiener index & $-\sum\left(\frac{n_{i}}{N} \times \ln \left(\frac{n_{i}}{N}\right)\right)$ & - & $\begin{aligned} \mathrm{n}_{\mathrm{i}}= & \text { total of individuals of species } \mathrm{i}, \mathrm{N}=\text { total of } \\
& \text { individuals of all species in the habitat }\end{aligned}$ \\
\hline 7 & Similarity index & $\begin{array}{c}\frac{(2 R s+R s s)}{2+1} \\
\text { Where: } \\
R s=\frac{x+y-z}{x+y+z}, \text { and } \\
R s s=\frac{x^{\prime}+y^{\prime}-z^{\prime}}{x^{\prime}+y^{\prime}+z^{\prime}}\end{array}$ & - & $\begin{array}{c}\text { Rs = similarity level of species } \\
\text { Rss = similarity of subspecies } \\
\mathrm{x}\left(\mathrm{x}^{\prime}\right) ; \mathrm{y}\left(\mathrm{y}^{\prime}\right)=\text { number of species (number of } \\
\text { subspecies) found only in one habitat } \\
\mathrm{z}\left(\mathrm{z}^{\prime}\right)=\text { number of species (number of subspecies) found } \\
\text { in both habitats. Range of values: }-1 \text { to }-0.7=\text { very } \\
\text { similar, }<-0.7 \text { to }-0.35=\text { similar, }<-0.35 \text { to } 0=\text { tend to } \\
\text { be similar, } 0 \text { to }<0.35=\text { tend to be different, } 0.35 \text { to }<0.7 \\
=\text { different, } 0.7 \text { to } 1.0=\text { very different }\end{array}$ \\
\hline
\end{tabular}

Table A4. Occurrence frequency of earthworm species by habitat (codes as in Table A2).

\begin{tabular}{|c|c|c|c|c|c|c|c|c|}
\hline \multirow{2}{*}{ Species } & \multicolumn{7}{|c|}{ Occurrence Frequency by Habitat (\%) } & \multirow{2}{*}{ No. of Habitat * } \\
\hline & NF & RF & GL & PF & AF & UC & HG & \\
\hline \multicolumn{9}{|l|}{ Family Rhinodrilidae } \\
\hline Pontoscolex corethrurus & 16 & 48 & 74 & 92 & 89 & 76 & 94 & 7 \\
\hline \multicolumn{9}{|l|}{ Family Moniligastridae } \\
\hline Drawida beddardi & 34 & 30 & 3.5 & & 4.5 & & & 4 \\
\hline \multicolumn{9}{|l|}{ Family Megascolecidae } \\
\hline Amynthas alluxus & 7 & 3 & & 3 & 2.5 & & & 4 \\
\hline Amynthas aspergillum & 25 & 32 & 20 & 18 & 6 & 2 & 10 & 7 \\
\hline Amynthas cortices & 9 & & & 2 & 2 & & & 3 \\
\hline Amynthas divitopapillatus & 12 & 12 & 12 & 12 & 12 & 12 & 12 & 7 \\
\hline Amynthas exiguus austrinus & 10 & & & 2 & & & & 2 \\
\hline Amynthas exiguus chomontis & & 2 & 10 & 2 & 5 & & & 4 \\
\hline Amynthas falcipapillatus & 4 & & & & & & & 1 \\
\hline Amynthas infantiloides & 4 & 3 & & & & & & 2 \\
\hline Amynthas modiglianii & 13 & 34 & 30 & 6 & 8 & 7 & 10 & 7 \\
\hline Amynthas zoysiae & & & 10 & & 2 & & & 2 \\
\hline Amynthas wui & & 6 & & & & & & 1 \\
\hline Amynthas sp.1 & 9 & 32 & 50 & 7 & 23 & 4 & 40 & 7 \\
\hline Amynthas sp.2 & 24 & 18 & & 2 & 2.5 & & & 4 \\
\hline Amynthas sp.3 & 9 & 3 & & 3 & 2 & & & 4 \\
\hline Amynthas sp.4 & 9 & 1 & & & & & & 2 \\
\hline Amynthas sp.5 & 20 & 11 & & 2 & & & & 3 \\
\hline
\end{tabular}


Table A4. Cont.

\begin{tabular}{|c|c|c|c|c|c|c|c|c|}
\hline \multirow{2}{*}{ Species } & \multicolumn{7}{|c|}{ Occurrence Frequency by Habitat (\%) } & \multirow{2}{*}{ No. of Habitat * } \\
\hline & NF & RF & GL & PF & AF & UC & HG & \\
\hline \multicolumn{9}{|l|}{ Family Megascolecidae } \\
\hline Amynthas sp.6 & 6 & 6 & & & & & & 2 \\
\hline Amynthas sp.7 & 4 & 1 & & & & & & 2 \\
\hline Metapheretima tiencanhensis & 13 & 30 & 20 & 12 & 12 & & & 5 \\
\hline Metaphire houlleti & 20 & 20 & 20 & 20 & 20 & 20 & 20 & 7 \\
\hline Metaphire sp.1 & & & & 1 & & & & 1 \\
\hline Polypheretima sp.1 & 4 & 14 & 30 & 4 & & & & 4 \\
\hline Polypheretima taprobanae & 20 & 32 & 17 & 8 & 9 & 2 & 14 & 7 \\
\hline Total number of species & 21 & 20 & 12 & 14 & 15 & 7 & 7 & \\
\hline
\end{tabular}

Table A5. Quantity ( $\left.\mathrm{n}^{\prime}\right)$ and biomass (b') dominance (\%) of earthworm species by habitat and soil depth (NF: natural forest, RF: regenerated forest, GL: grasslands, PF: planted forest, AF: agroforestry, UC: upland annual crops, HG: home gardens).

\begin{tabular}{|c|c|c|c|c|c|c|c|c|c|c|c|c|c|c|}
\hline \multirow{2}{*}{ Species } & \multicolumn{2}{|c|}{ NF } & \multicolumn{2}{|c|}{ RF } & \multicolumn{2}{|c|}{ GL } & \multicolumn{2}{|c|}{ PF } & \multicolumn{2}{|c|}{ AF } & \multicolumn{2}{|c|}{ UC } & \multicolumn{2}{|c|}{ HG } \\
\hline & $\mathbf{n}^{\prime}$ & $\mathbf{b}^{\prime}$ & $\mathbf{n}^{\prime}$ & $\mathbf{b}^{\prime}$ & $\mathbf{n}^{\prime}$ & $\mathbf{b}^{\prime}$ & $\mathbf{n}^{\prime}$ & $\mathbf{b}^{\prime}$ & $\mathbf{n}^{\prime}$ & $\mathbf{b}^{\prime}$ & $\mathbf{n}^{\prime}$ & $\mathbf{b}^{\prime}$ & $\mathbf{n}^{\prime}$ & $\mathbf{b}^{\prime}$ \\
\hline \multicolumn{15}{|c|}{ Pontoscolex corethrurus } \\
\hline $0-10$ & 1.7 & 1.2 & 35.7 & 13.6 & 48.6 & 13.8 & 91.1 & 51.8 & 90.1 & 61.8 & 85.4 & 70.6 & 88.4 & 65.8 \\
\hline $10-20$ & 6.7 & 2.2 & 30.7 & 7.3 & 47.4 & 19.0 & 85.6 & 76.6 & 86.8 & 43.4 & 95.6 & 92.6 & 44.3 & 10.5 \\
\hline $20-30$ & 3.2 & 0.5 & 12.9 & 6.0 & 45.4 & 13.7 & 82.0 & 56.2 & 60.7 & 33.9 & 89.6 & 60.8 & 56.5 & 40.5 \\
\hline \multicolumn{15}{|c|}{ Drawida beddardi } \\
\hline $0-10$ & 2.3 & 0.9 & 11.7 & 3.7 & & & & & 0.4 & 1.1 & & & & \\
\hline $10-20$ & 10.5 & 18.9 & 9.1 & 2.7 & 0.4 & 0.0 & & & & & & & & \\
\hline $20-30$ & 4.7 & 1.4 & 9.1 & 1.1 & & & & & 2.2 & 0.4 & & & & \\
\hline \multicolumn{15}{|c|}{ Amynthas alluxus } \\
\hline $0-10$ & 0.4 & 0.0 & 1.2 & 0.3 & & & & & & & & & & \\
\hline $10-20$ & & & 7.6 & 3.4 & & & 0.7 & 0.7 & & & & & & \\
\hline $20-30$ & 6.3 & 2.3 & & & & & & & & & & & & \\
\hline \multicolumn{15}{|c|}{ Amynthas aspergillum } \\
\hline $0-10$ & 2.3 & 16.1 & 1.4 & 19.2 & 2.4 & 29.7 & 2.1 & 34.0 & & & & & 2.0 & 26.6 \\
\hline $10-20$ & 6.7 & 30.9 & 6.7 & 59.8 & 1.3 & 25.7 & 0.2 & 8.5 & 0.7 & 48.1 & & & 2.2 & 34.0 \\
\hline $20-30$ & 8.4 & 72.1 & 7.8 & 70.9 & 1.7 & 35.4 & 0.8 & 20.4 & 0.7 & 29.3 & 0.6 & 13.4 & 2.0 & 17.8 \\
\hline \multicolumn{15}{|c|}{ Amynthas corticis } \\
\hline $0-10$ & 1.5 & 2.6 & & & & & & & & & & & & \\
\hline $10-20$ & 1.4 & 1.6 & & & & & & & 0.3 & 1.1 & & & & \\
\hline $20-30$ & 0.5 & 0.4 & & & & & & & & & & & & \\
\hline \multicolumn{15}{|c|}{ Amynthas divitopapillatus } \\
\hline $0-10$ & 0.8 & 1.3 & & & & & & & & & & & & \\
\hline $10-20$ & 0.5 & 0.2 & & & & & & & & & & & & \\
\hline $20-30$ & 0.5 & 0.2 & & & & & & & & & & & & \\
\hline \multicolumn{15}{|c|}{ Amynthas exiguus austrinus } \\
\hline 0-10 & 10.5 & 3.5 & 0.5 & 0.1 & & & & & & & & & & \\
\hline $10-20$ & 5.8 & 2.7 & & & 2.4 & 0.1 & 0.7 & 0.2 & 3.3 & 0.3 & & & & \\
\hline $20-30$ & 18.8 & 1.5 & & & & & & & 18.2 & 2.8 & 0.6 & 0.1 & & \\
\hline \multicolumn{15}{|c|}{ Amynthas exiguus chomontis } \\
\hline $0-10$ & & & & & & & & & & & & & & \\
\hline $10-20$ & & & & & 2.4 & 0.1 & & & 3.3 & 0.3 & & & & \\
\hline $20-30$ & & & 1.2 & 0.0 & & & & & 18.2 & 2.8 & & & & \\
\hline
\end{tabular}


Table A5. Cont.

\begin{tabular}{|c|c|c|c|c|c|c|c|c|c|c|c|c|c|c|}
\hline \multirow{2}{*}{ Species } & \multicolumn{2}{|c|}{ NF } & \multicolumn{2}{|c|}{ RF } & \multicolumn{2}{|c|}{ GL } & \multicolumn{2}{|c|}{ PF } & \multicolumn{2}{|c|}{ AF } & \multicolumn{2}{|c|}{ UC } & \multicolumn{2}{|c|}{ HG } \\
\hline & $\mathbf{n}^{\prime}$ & $\mathbf{b}^{\prime}$ & $\mathbf{n}^{\prime}$ & $\mathbf{b}^{\prime}$ & $\mathbf{n}^{\prime}$ & $\mathbf{b}^{\prime}$ & $\mathbf{n}^{\prime}$ & $\mathbf{b}^{\prime}$ & $\mathbf{n}^{\prime}$ & $\mathbf{b}^{\prime}$ & $\mathbf{n}^{\prime}$ & $\mathbf{b}^{\prime}$ & $\mathbf{n}^{\prime}$ & $\mathbf{b}^{\prime}$ \\
\hline \multicolumn{15}{|c|}{ Amynthas falcipapillatus } \\
\hline $\begin{array}{c}0-10 \\
10-20 \\
20-30\end{array}$ & 1.4 & 1.0 & & & & & & & & & & & & \\
\hline \multicolumn{15}{|c|}{ Amynthas infantiloides } \\
\hline $0-10$ & & & & & & & & & 0.8 & 5.8 & & & & \\
\hline $10-20$ & 3.8 & 0.6 & 0.9 & 0.1 & & & & & 0.7 & 2.1 & & & & \\
\hline $20-30$ & 9.4 & 0.7 & 1.4 & 0.0 & & & & & 1.1 & 4.1 & & & & \\
\hline \multicolumn{15}{|c|}{ Amynthas modiglianii } \\
\hline $0-10$ & 5.1 & 13.9 & 16.8 & 27.7 & 13.2 & 26.1 & 1.7 & 7.8 & 2.0 & 17.5 & 1.0 & 10.5 & 0.3 & 0.4 \\
\hline $10-20$ & 2.9 & 10.7 & 2.3 & 2.7 & & & & & & & & & & \\
\hline $20-30$ & & & & & & & 5.1 & 10.8 & & & & & & \\
\hline \multicolumn{15}{|c|}{ Amynthas zoysiae } \\
\hline $0-10$ & & & & & 0.9 & 0.1 & & & & & & & & \\
\hline $10-20$ & & & & & 4.8 & 0.8 & & & & & 1.2 & 1.0 & & \\
\hline $20-30$ & & & & & & & & & 0.7 & 0.1 & & & & \\
\hline \multicolumn{15}{|c|}{ Amynthas wui } \\
\hline $\begin{array}{c}0-10 \\
10-20 \\
20-30\end{array}$ & & & 0.1 & 0.0 & & & & & & & & & & \\
\hline \multicolumn{15}{|c|}{ Amynthas sp.1 } \\
\hline $0-10$ & 1.5 & 0.1 & 1.9 & 0.1 & 5.3 & 0.1 & 0.7 & 0.1 & 1.4 & 0.2 & & & 3.1 & 0.5 \\
\hline $10-20$ & 2.9 & 0.5 & 5.8 & 0.2 & 24.7 & 1.6 & 7.1 & 1.6 & 2.3 & 0.3 & 0.6 & 0.7 & 50.0 & 50.0 \\
\hline $20-30$ & 2.7 & 0.0 & 10.5 & 0.4 & 17.9 & 0.6 & 8.4 & 0.9 & 9.8 & 3.1 & & & 22.2 & 15.5 \\
\hline \multicolumn{15}{|c|}{ Amynthas sp.2 } \\
\hline $0-10$ & 10.5 & 0.8 & 2.7 & 0.2 & & & & & 0.4 & 0.1 & & & & \\
\hline $10-20$ & 11.5 & 1.6 & 4.2 & 0.2 & & & & & & & & & & \\
\hline $20-30$ & 3.1 & 0.1 & 1.7 & 0.1 & & & & & & & & & & \\
\hline \multicolumn{15}{|c|}{ Amynthas sp.3 } \\
\hline $0-10$ & 1.3 & 0.1 & & & & & & & & & & & & \\
\hline $10-20$ & 2.9 & 0.3 & 0.8 & 0.1 & & & & & & & & & & \\
\hline $20-30$ & 3.7 & 0.1 & & & & & 1.0 & 4.2 & 4.5 & 4.5 & 2.1 & 0.8 & & \\
\hline \multicolumn{15}{|c|}{ Amynthas sp.4 } \\
\hline $0-10$ & 2.4 & 2.3 & & & & & & & & & & & & \\
\hline $10-20$ & 1.0 & 0.9 & & & & & & & & & & & & \\
\hline $20-30$ & & & & & & & & & & & & & & \\
\hline \multicolumn{15}{|c|}{ Amynthas sp.5 } \\
\hline $0-10$ & 19.7 & 0.9 & 1.0 & 0.1 & & & & & & & 9.1 & 1.2 & & \\
\hline $10-20$ & 9.5 & 0.1 & 2.8 & 0.1 & & & 0.2 & 0.5 & & & 0.9 & 0.2 & & \\
\hline $20-30$ & 13.3 & 0.4 & & & & & & & & & 0.6 & 13.4 & & \\
\hline \multicolumn{15}{|c|}{ Amynthas sp.6 } \\
\hline $0-10$ & 1.4 & 0.2 & 0.5 & 0.0 & & & & & & & & & & \\
\hline $10-20$ & 1.9 & 0.2 & & & & & & & & & & & & \\
\hline 20-30 & & & 0.6 & 0.0 & & & & & & & & & & \\
\hline & & & & & & $A m$ & has sp & & & & & & & \\
\hline $0-10$ & 0.6 & 0.6 & & & & & & & & & & & & \\
\hline $10-20$ & 1.9 & 1.5 & 0.4 & 0.1 & & & & & & & & & & \\
\hline 20-30 & & & & & & & & & & & & & & \\
\hline
\end{tabular}


Table A5. Cont.

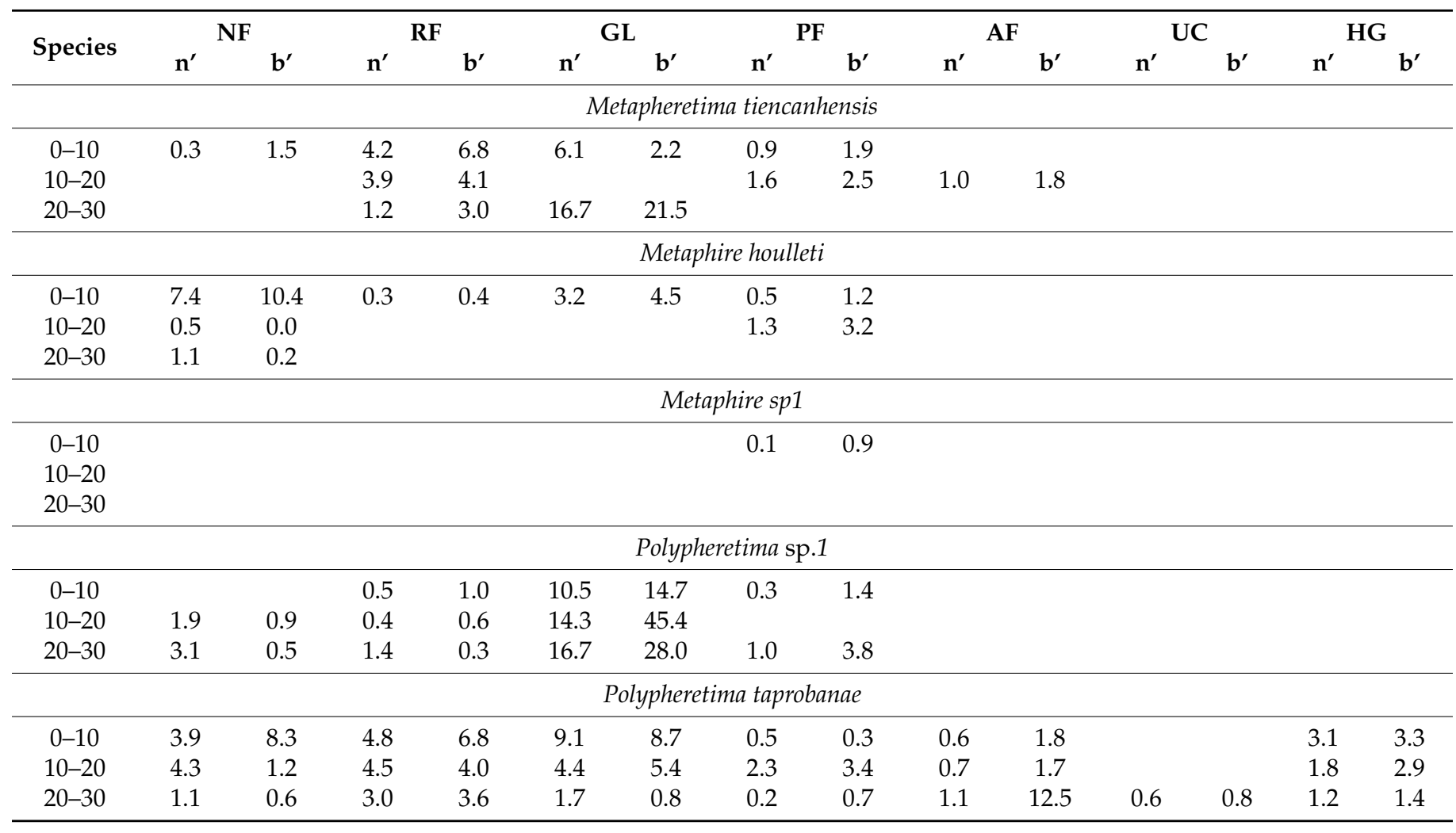

\section{References}

1. Meyfroidt, P.; Lambin, E.F. Forest transition in Vietnam and displacement of deforestation abroad. Proc. Natl. Acad. Sci. USA 2009, 106, 16139-16144. [CrossRef] [PubMed]

2. Barbier, E.B.; Burgess, J.C.; Grainger, A. The forest transition: Towards a more comprehensive theoretical framework. Land Use Policy 2010, 27, 98-107. [CrossRef]

3. Meyfroidt, P.; Lambin, E.F. Global forest transition: Prospects for an end to deforestation. Annu. Rev. Environ. Resour. 2011, 36, 343-371. [CrossRef]

4. Tomich, T.P.; Thomas, D.E.; Van Noordwijk, M. Environmental services and land use change in Southeast Asia: From recognition to regulation or reward? In Proceedings of the Agriculture, Ecosystems and Environment; Elsevier: Amsterdam, The Netherlands, 2004; Volume 104, pp. 229-244.

5. Leimona, B.; van Noordwijk, M.; de Groot, R.; Leemans, R. Fairly efficient, efficiently fair: Lessons from designing and testing payment schemes for ecosystem services in Asia. Ecosyst. Serv. 2015, 12, 16-28. [CrossRef]

6. Bruijnzeel, L.A. Hydrological functions of tropical forests: Not seeing the soil for the trees? In Proceedings of the Agriculture, Ecosystems and Environment; Elsevier: Amsterdam, The Netherlands, 2004; Volume 104, pp. 185-228.

7. Wall, D.H.; Nielsen, U.N. Biodiversity and ecosystem services: Is it the same below ground? Nat. Educ. Knowl. $2012,3,8$.

8. Delgado-Baquerizo, M.; Bardgett, R.D.; Vitousek, P.M.; Maestre, F.T.; Williams, M.A.; Eldridge, D.J.; Lambers, H.; Neuhauser, S.; Gallardo, A.; García-Velázquez, L.; et al. Changes in belowground biodiversity during ecosystem development. Proc. Natl. Acad. Sci. USA 2019, 116, 6891-6896. [CrossRef] [PubMed]

9. Wagg, C.; Bender, S.F.; Widmer, F.; Van Der Heijden, M.G.A. Soil biodiversity and soil community composition determine ecosystem multifunctionality. Proc. Natl. Acad. Sci. USA 2014, 111, 5266-5270. [CrossRef] [PubMed]

10. Greacen, E.; Sands, R. Compaction of forest soils. A review. Aust. J. Soil Res. 1980, 18, 163-189. [CrossRef]

11. Ruiz, S.; Schymanski, S.J.; Or, D. Mechanics and energetics of soil penetration by earthworms and plant roots: Higher rates cost more. Vadose Zone J. 2017, 16, vzj2017.01.0021. [CrossRef]

12. World Bank. Country Forest Note Vietnam; World Bank: Washington DC, USA, 2019.

13. To, X.P.; Tran, H.N. Forest Land Allocation in the Context of Forestry Sector Restructuring: Opportunities for Forestry Development and Upland Livelihood Improvement; Tropenbos International Vietnam: Hue City, Vietnam, 2014.

14. de Jong, W.; Do, D.S.; Trieu, V.H. Forest Rehabilitation in Vietnam: Histories, Realities and Future; Center for International Forestry Research (CIFOR): Jakarta, Indonesia, 2006.

15. Le, D.M.; Nguyen, M.H.; Tran, T. Deforestation in the Central Highlands: Implications for minority ethnic communities and a number of recommendations. In Proceedings of the 14th International Conference on Humanities and Social Sciences 2018 (IC-HUSO 2018), Khon Kaen, Thailand, 22-23 November 2018; pp. 491-507. 
16. Catacutan, D.C.; Do, T.H.; Simelton, E.; Hanh, V.T.; Hoang, T.L.; Patton, I.; Hairiah, K.; Le, T.T.; van Noordwijk, M.; Nguyen, M.P.; et al. Assessment of the Livelihoods and Ecological Conditions of Bufferzone Communes in Song Thanh National Reserve, Quang Nam Province, and Phong Dien Natural Reserve, Thua Thien Hue Province; World Agroforestry (ICRAF): Hanoi, Vietnam, 2017.

17. Nguyen, H.T.; Yen, H.M. Song Thanh Nature Reserve. In Evidence-Based Conservation. Lessons from the Lower Mekong; Sunderland, T.C.H., Sayer, J., Hoang, M.H., Eds.; Center for International Forestry Research: Bogor, Indonesia, 2013; pp. 29-38.

18. FAO. Vietnam Forestry Outlook Study; FAO: Bangkok, Thailand, 2009.

19. MONRE. Vietnam's Fifth National Report to the United Nations Convention on Biological Diversity (Reporting Period: 2009-2013); MONRE: Hanoi, Vietnam, 2014.

20. Bartz, M.L.C.; Brown, G.G.; da Rosa, M.G.; Filho, O.K.; James, S.W.; Decaëns, T.; Baretta, D. Earthworm richness in land-use systems in Santa Catarina, Brazil. Appl. Soil Ecol. 2014, 83, 59-70. [CrossRef]

21. Shakir, S.H.; Dindal, D.L. Density and biomass of earthworms in forest and herbaceous microecosystems in central New York, North America. Soil Biol. Biochem. 1997, 29, 275-285. [CrossRef]

22. Zhang, H.; Schrader, S. Earthworm effects on selected physical and chemical properties of soil aggregates. Biol. Fertil. Soils 1993, 15, 229-234. [CrossRef]

23. Blouin, M.; Hodson, M.E.; Delgado, E.A.; Baker, G.; Brussaard, L.; Butt, K.R.; Dai, J.; Dendooven, L.; Peres, G.; Tondoh, J.E.; et al. A review of earthworm impact on soil function and ecosystem services. Eur. J. Soil Sci. 2013, 64, 161-182. [CrossRef]

24. Lavelle, P.; Barois, I.; Cruz, I.; Fragoso, C.; Hernandez, A.; Pineda, A.; Rangel, P. Adaptive strategies of Pontoscolex corethrurus (Glossoscolecidae, Oligochaeta), a peregrine geophagous earthworm of the humid tropics. Biol. Fertil. Soils 1987, 5, 188-194. [CrossRef]

25. González, G.; Huang, C.Y.; Zou, X.; Rodríguez, C. Earthworm invasions in the tropics. In Biological Invasions Belowground: Earthworms as Invasive Species; Springer: Berlin/Heidelberg, Germany, 2006; pp. 47-56, ISBN 1402052820.

26. Bhadauria, T.; Ramakrishnan, P.S. Earthworm population dynamics and contribution to nutrient cycling during cropping and fallow phases of shifting agriculture (Jhum) in North-East India. J. Appl. Ecol. 1989, 26, 505. [CrossRef]

27. Nunes, D.H.; Pasini, A.; Benito, N.P.; Brown, G.G. Earthworm diversity in four land use systems in the region of Jaguapitã, Paraná State, Brazil. Caribb. J. Sci. 2006, 42, 331-338.

28. Singh, S.; Singh, J.; Vig, A.P. Effect of abiotic factors on the distribution of earthworms in different land use patterns. J. Basic Appl. Zool. 2016, 74, 41-50. [CrossRef]

29. Tao, Y.; Gu, W.; Chen, J.; Tao, J.; Xu, Y.J.; Zhang, H. The influence of land use practices on earthworm communities in saline agriculture soils of the west coast region of China's Bohai Bay. Plant Soil Environ. 2013, 59, 8-13. [CrossRef]

30. Rajkhowa, D.J.; Bhattacharyya, P.N.; Sarma, A.K.; Mahanta, K. Diversity and distribution of earthworms in different soil habitats of Assam, North-East India, an Indo-Burma biodiversity hotspot. Proc. Natl. Acad. Sci. India Sect. B-Biol. Sci. 2015, 85, 389-396. [CrossRef]

31. Dewi, W.S.; Senge, M. Earthworm diversity and ecosystem services under threat. Rev. Agric. Sci. 2015, 3, 25-35. [CrossRef]

32. ICEM. Strategic Environmental Assessment of the Quang Nam Province Hydropower Plan for the Vu Gia-Thu Bon River Basin; ICEM: Hanoi, Vietnam, 2008.

33. Mulia, R.; Khasanah, N.; Catacutan, D. Alternative forest plantation systems for Southcentral Coast of Vietnam: Projections of growth and production using the WaNuLCAS model. In Towards Low-Emission Landscapes in Vietnam; Mulia, R., Simelton, E., Eds.; World Agroforestry (ICRAF) Vietnam, World Agroforestry (ICRAF) Southeast Asia Regional Program: Hanoi, Vietnam, 2018; pp. $45-60$.

34. Górny, M.; Grüm, L. Methods in Soil Zoology; Elsevier Science: Amsterdam, The Netherlands, 1993.

35. Gates, G.E. Burmese earthworms: An introduction to the systematics and biology of Megadrile Oligochaetes with special reference to Southeast Asia. Trans. Am. Philos. Soc. 1972, 62, 1. [CrossRef]

36. Sims, R.W.; Easton, E.G. A numerical revision of the earthworm genus Pheretima auct. (Megascolecidae: Oligochaeta) with the recognition of new genera and an appendix on the earthworms collected by the Royal Society North Borneo Expedition. Biol. J. Linn. Soc. 1972, 4, 169-268. [CrossRef]

37. Pham, T.H. The earthworm fauna of Quang Nam-Da Nang, Hanoi National University of Education. Ph.D. Thesis, Hanoi National University, Hanoi, Vietnam, 1995.

38. Nguyen, T.T.; Tran, B.T.T.; Nguyen, A.D. Earthworms of the "acaecate" Pheretima group in Vietnam (Oligochaeta: Megascolecidae), with description of a new species from the Mekong delta. Zootaxa 2014, 3866, 105-121. [CrossRef] [PubMed]

39. Thai, T. Earthworms of Vietnam (Systematic, Fauna, Distribution and Zoogeographic). Ph.D.Thesis, Lomonosov Moscow State University, Moscow, Russia, 1983.

40. Thai, T.B. New species of the genus Pheretima in Vietnam. Zool. J. 1984, 63, 1317-1327.

41. Thai, T.B. New species and subspecies of the genus Pheretima (Oligochaeta, Megascolecidae) from Vietnam. Zool. J. 1984, 63, 613-617.

42. Nguyen, T.T.; Nguyen, A.D.; Tran, B.T.T.; Blakemore, R.J. A comprehensive checklist of earthworm species and subspecies from Vietnam (Annelida: Clitellata: Oligochaeta: Almidae, Eudrilidae, Glossoscolecidae, Lumbricidae, Megascolecidae, Moniligastridae, Ocnerodrilidae, Octochaetidae). Zootaxa 2016, 4140, 1-92. [CrossRef]

43. Thai, T.B. Description of five new species of the acaecate earthworms of the genus Pheretima Kinberg in Vietnam and key to the species of acaecate Pheretima recorded from Indochinese area. J. Biol. 1996, 18, 1-6. 
44. Shannon, C.E.; Weaver, W. The Mathematical Theory of Communication; University of Illinois Press: Urbana, IL, USA, 1949.

45. Stugren, B.; Radulescu, M. Metode matematice in zoogeografia regionala. Studies Univ. Babes-Bolyai Biol. 1961, 18, 8-24.

46. Gonzalez, G.; Zou, X. Plant and litter influences on earthworm abundance and community structure in a tropical wet forest. Biotropica 1999, 31, 486-493. [CrossRef]

47. Dechaine, J.; Ruan, H.; Sanchez-De Leon, Y.; Zou, X. Correlation between earthworms and plant litter decomposition in a tropical wet forest of Puerto Rico. Pedobiologia (Jena) 2005, 49, 601-607. [CrossRef]

48. Sangha, K.K.; Jalota, R.K.; Midmore, D.J. Litter production, decomposition and nutrient release in cleared and uncleared pasture systems of central Queensland, Australia. J. Trop. Ecol. 2006, 22, 177-189. [CrossRef]

49. Van Noordwijk, M.; Hairiah, K. Rapid carbon stock appraisal. In Negotiation-Support Toolkit for Learning Landscapes; van Noordwijk, M., Lusiana, B., Leimona, B., Dewi, S., Wulandari, D., Eds.; World Agroforestry (ICRAF), Southeast Asia Regional Program: Bogor, Indonesia, 2013.

50. Chakravarty, S.; Prakash, R.; Vineeta, N.A.; Pala, G.S. Litter production and decomposition in tropical forest. In Handbook of Research on the Conservation and Restoration of Tropical Dry Forests; Bhadouria, R., Ed.; IGI Global: Hershey, PA, USA, 2020; pp. 193-212.

51. Cardinael, R.; Umulisa, V.; Toudert, A.; Olivier, A.; Bockel, L.; Bernoux, M. Revisiting IPCC Tier 1 coefficients for soil organic and biomass carbon storage in agroforestry systems. Environ. Res. Lett. 2018, 13, 124020. [CrossRef]

52. Barros, E.; Curmi, P.; Hallaire, V.; Chauvel, A.; Lavelle, P. The role of macrofauna in the transformation and reversibility of soil structure of an oxisol in the process of forest to pasture conversion. Geoderma 2001, 100, 193-213. [CrossRef]

53. Hauser, S. Distribution and activity of earthworms and contribution to nutrient recycling in alley cropping. Biol. Fertil. Soils 1993, 15, 16-20. [CrossRef]

54. Hauser, S.; Asawalam, D.O.; Vanlauwe, B. Spatial and temporal gradients of earthworm casting activity in alley cropping systems. Agrofor. Syst. 1998, 41, 127-137. [CrossRef]

55. Marsden, C.; Martin-Chave, A.; Cortet, J.; Hedde, M.; Capowiez, Y. How agroforestry systems influence soil fauna and their functions-a review. Plant Soil 2020, 453, 29-44. [CrossRef]

56. Norgrove, L.; Csuzdi, C.; Forzi, F.; Canet, M.; Gounes, J. Shifts in soil faunal community structure in shaded cacao agroforests and consequences for ecosystem function in Central Africa. Trop. Ecol. 2009, 50, 71-78.

57. Sánchez-De León, Y.; De Melo, E.; Soto, G.; Johnson-Maynard, J.; Lugo-Pérez, J. Earthworm populations, microbial biomass and coffee production in different experimental agroforestry management systems in Costa Rica. Caribb. J. Sci. 2006, 42, 397-409.

58. Cardinael, R.; Hoeffner, K.; Chenu, C.; Chevallier, T.; Béral, C.; Dewisme, A.; Cluzeau, D. Spatial variation of earthworm communities and soil organic carbon in temperate agroforestry. Biol. Fertil. Soils 2019, 55, 171-183. [CrossRef]

59. Tian, G.; Olimah, J.A.; Adeoye, G.O.; Kang, B.T. Regeneration of earthworm populations in a degraded soil by natural and planted fallows under humid tropical conditions. Soil Sci. Soc. Am. J. 2000, 64, 222-228. [CrossRef]

60. Price, G.W.; Gordon, A.M. Spatial and temporal distribution of earthworms in a temperate intercropping system in southern Ontario, Canada. Agrofor. Syst. 1998, 44, 141-149. [CrossRef]

61. Taheri, S.; Pelosi, C.; Dupont, L. Harmful or useful? A case study of the exotic peregrine earthworm morphospecies Pontoscolex corethrurus. Soil Biol. Biochem. 2018, 116, 277-289. [CrossRef]

62. Nguyen, V.T. The Earthworm Fauna of Binh Tri Thien Region; Hanoi National University of Education: Hanoi, Vietnam, 1994.

63. Thai, T.B. Species diversity of earthworms in Vietnam. In Proceedings of the National Workshop on the Basic Issues in Life Science; Hanoi Science and Technics Publishing House: Hanoi, Vietnam, 2000; pp. 307-311.

64. Thai, T.B.; Huynh, T.K.H.; Nguyen, D.A. Remarks of earthworms on the islands in southern of Vietnam. In Proceedings of the National Workshop on the Basic Issues in Life Science; Hanoi Science and Technics Publishing House: Hanoi, Vietnam, 2004; pp. 757-760.

65. Fragoso, C.; Kanyonyo, J.; Moreno, A.; Senapati, B.K.; Blanchart, E.; Rodriguez, C. A survey of tropical earthworms: Taxonomy, biogeography and environmental plasticity. In Earthworm Management in Tropical Agroecosystems; Lavelle, P., Brussaard, L., Hendrix, P., Eds.; CAB International: Wallingford, UK, 1999; pp. 27-55.

66. Williamson, M.; Fitter, A. The varying success of invaders. Ecology 1996, 77, 1661-1666. [CrossRef]

67. Alegre, J.C.; Pashanasi, B.; Lavelle, P. Dynamics of soil physical properties in Amazonian agroecosystems inoculated with earthworms. Soil Sci. Soc. Am. J. 1996, 60, 1522-1529. [CrossRef]

68. Blanchart, E.; Lavelle, P.; Braudeau, E.; Le Bissonnais, Y.; Valentin, C. Regulation of soil structure by geophagous earthworm activities in humid savannas of Cote d'Ivoire. Soil Biol. Biochem. 1997, 29, 431-439. [CrossRef]

69. Chauvel, A.; Grimaldi, M.; Barros, E.; Blanchart, E.; Desjardins, T.; Sarrazin, M.; Lavelle, P. Pasture damage by an Amazonian earthworm. Nature 1999, 398, 32-33. [CrossRef]

70. Hallaire, V.; Curmi, P.; Duboisset, A.; Lavelle, P.; Pashanasi, B. Soil structure changes induced by the tropical earthworm Pontoscolex corethrurus and organic inputs in a Peruvian ultisol. Eur. J. Soil Biol. 2000, 36, 35-44. [CrossRef]

71. Sparovek, G.; Lambais, M.R.; Silva, Á.P.d.; Tormena, C.A. Earthworm (Pontoscolex corethrurus) and organic matter effects on the reclamation of an eroded oxisol. Pedobiologia (Jena) 1999, 43, 698-704.

72. Brown, G.G.; James, S.W.; Pasini, A.; Nunes, D.H.; Benito, N.P.; Martins, P.T.; Sautter, K. Exotic, peregrine, and invasive earthworms in Brazil: Diversity, distribution, and effects on soils and plants. Caribb. J. Sci. 2006, 42, 339-358. 
73. Bamgbose, O.; Odukoya, O.; Arowolo, T. Earthworms as bio-indicators of metal pollution in dump sites of Abeokuta City, Nigeria. Rev. Biol. Trop 2000, 48, 229-234.

74. Suthar, S.; Singh, S.; Dhawan, S. Earthworms as bioindicator of metals ( $\mathrm{Zn}, \mathrm{Fe}, \mathrm{Mn}, \mathrm{Cu}, \mathrm{Pb}$ and $\mathrm{Cd}$ ) in soils: Is metal bioaccumulation affected by their ecological category? Ecol. Eng. 2008, 32, 99-107. [CrossRef]

75. Fründ, H.-C.; Graefe, U.; Tischer, S. Earthworms as bioindicators of soil quality. In Biology of Earthworms; Karaca, A., Ed.; Springer: Berli/Heidelberg, Germany, 2011; pp. 261-278.

76. Hirano, T.; Tamae, K. Earthworms and soil pollutants. Sensors 2011, 11, 11157-11167. [CrossRef] [PubMed]

77. Nguyen, T.T.; Tran, T.T.B.; Lam, H.D.; Nguyen, A.D. Four new species of Amynthas earthworms in southeastern Vietnam (Annelida, Oligochaeta, Megascolecidae). Zootaxa 2020, 4790, 277-290. [CrossRef] [PubMed]

78. Hong, Y. New earthworm species of Amynthas (Clitellata: Megascolecidae) from Nam Phouin National Protected Area, Laos. J. Asia-Pac. Biodivers. 2019, 12, 353-356. [CrossRef] 